\title{
RIDDLES AS INDICATOR OF CULTURAL AND LINGUISTIC CONVERGENCE IN THE GURAGE REGION*
}

\section{Ethiopia as a language and culture area}

More than 70 languages belonging to four different language groups are spoken in Ethiopia. ${ }^{1}$ Most of these languages have only a few thousand speakers, who are usually bi- or multilingual. ${ }^{2}$ Also among speakers of major languages bi- and multilingualism is a very widespread phenomenon. The majority of Ethiopian languages are not taught at schools. Speakers gain their proficiency in second languages from face-to-face contacts. This multilingualism is not a recent development but has prevailed for several centuries, as Ethiopian languages have converged in parts of their lexicon, grammar and syntax. The investigation of the Ethiopian language convergence area has been a major topic both in Ethiopian studies ${ }^{3}$ and in general linguistics for a long time. ${ }^{4}$

${ }^{*}$ I am grateful to the German Academic Exchange Service (DAAD; HSP III) and the SFB 295 Kulturelle und sprachliche Kontakte (Cultural and language contacts) at Mainz University financed by the German Research Foundation (Deutsche Forschungsgemeinschaft) who both have supported my several field stays in Ethiopia from 1998 through 2004. Furthermore, I thank the Institute of Ethiopian Studies (IES) at Addis Ababa University for its cooperation.

${ }^{1}$ The analysis and description of Ethiopian cultures and languages was one main topic in the work of the late Sevir B. Chernetsov, who, being interested in a number of topics ranging from the early medieval Ethiopian history to Ethiopian folklore painting, also focused soberly, but often with humor, on the connection between social, political and environmental circumstances, on the one hand, and cultural and languages developments, on the other hand. The present article has been inspired by Chernetsov (1980) [for the list of abbreviations used in this paper see p. 186-188], in which he investigates the creation of a socialist nomenclature for Amharic. He clearly outlines the historical roots of cognitive concepts and their influence on the respective choice of new terms among Amharic speakers.

${ }^{2}$ Cf. MEYer - Richter 2003:79ff.

${ }^{3}$ Cf. Fergusson 1976; Hayward 2000; Leslau 1945; 1952.

${ }^{4}$ Cf. Thomason - Kaufmann 1988:133ff. and Thomason 2001:86. Recently, Tosco 2000 has raised doubts about the linguistic hypotheses used to postulate the Ethiopian language convergence area and denies its existence. 
The Ethiopian culture or cultures have also drawn the attention of anthropologists and historians. Classical works most often suppose a common culture for all Ethiopian peoples. These works are biased in favor of the Christian highlanders, i.e. the ancestors of today's Amhara and Tigrinya speaking communities. ${ }^{5}$ For such authors convergence means unilateral assimilation of ethnic groups towards the favored «Amhara culture». The focus, therefore, is on a kind of imaginary cultural unity within Ethiopia. Levine even goes further and proposes an «Ethiopian culture area» characterized by several social and socio-economic features. ${ }^{6}$ Another kind of description of ethnic groups in Ethiopia and their respective cultures and histories deals mainly with single communities and pays little attention to the interrelationship between different neighboring groups and/or conquerors. ${ }^{7}$ Such descriptions concentrate on features which are characteristic for the particular ethnic group in a locally bounded context. Only a few works try to unite both aspects, i. e. to describe the specific features of an ethnic group in relation to a general Ethiopian context. ${ }^{8}$

In the following I will demonstrate how language and cultural contacts between neighboring communities can influence each other within a small area. I will deal with the Gurage languages Muher, Zay and Wolane. Gurage languages are spoken in an area whose boundaries extend roughly to the River Awash in the north, Lake Zway in the east and the River Gibe in the west and southwest. There are approximately twelve Gurage languages, which belong to two different sub-branches: East Gurage and Gunnän-Gurage. ${ }^{9}$ While Wolane and Zay belong to separate branches within East Gurage, Muher is a representative of Gunnän-Gurage. Beside Gurage languages, Amharic and Oromo are also of importance as linguae francae. While Oromo is restricted to the northern and eastern parts of the Gurage region, Amharic is the language of administration and education throughout Ethiopia. Most Gurage speakers are multilingual. Beside Amharic and/or Oromo they often speak further Gurage languages.

Historically, the Gurage region became a permanent part of the Ethiopian empire only at the end of the $19^{\text {th }}$ cent. Since then Amharic has grown continuously into its function as national lingua franca. Due to the changed sociopolitical circumstances a Gurage-«diaspora» emerged in Addis Ababa, which had an important function as intermediator between the government and the local people. ${ }^{10}$ However, long before Amharic started to influence Gurage

\footnotetext{
${ }^{5}$ Cf. among others Hammerschmidt 1967; PANKhURST 1955 and UllendorfF 1960.

${ }^{6}$ LEVINE 1974:46.

${ }^{7}$ Cf. Haberland 1963; HuntingFord 1955; Shack 1966.

${ }^{8}$ See for instance BRAUKÄMPER 1980; MARKAKIS 1998.

${ }^{9}$ Cf. Hetzron 1977.

${ }^{10}$ Cf. Markakis 1998.
} 
languages heavily, there were undoubtedly many permanent contacts with Oromo, especially for East Gurage and Kistane communities. These contacts started with the Jihad of Mohammed al-Ghazi (Grañn) in the $16^{\text {th }}$ cent. and continued with the Oromo migration from the southern parts of today's Ethiopia to the north.

Socio-economically, the Gurage have been said to belong to a common culture area characterized by the cultivation of Ensete edulis or false banana. ${ }^{11}$ At the borders of the Gurage area and in elevated places, however, cattle breeding and the cultivation of crops instead of Ensete edulis can also be found. In regard to religion Gurage are both Muslims and Christians. Local religious practices, too, such as Bož- and Dämw awit-cults, are still present. This diversity suggests that Gurage cultures in fact represent a network of several close and weak ties which are able to integrate or to react to innovations and contact-induced changes. ${ }^{12}$ The term «culture» is interpreted as communicative processes that result in social constructions of reality and their objectivations. ${ }^{13}$ Obviously, culture is not a static system but has the ability to change in the course of time.

\section{The riddle as research topic in verbal art}

Riddles, which are an important part of oral art, represent a special type of social phenomenon. ${ }^{14}$ Language is used to transfer social constructions or concepts between individuals. When in a region different communities have intense, long-lasting contacts without dominating each other - as is the case in the Gurage area - their languages and cultures may converge over time. But before giving a detailed description of the convergence processes in Muher, Wolane and Zay, I will deal with the genre of riddle from a general point of view.

The collection and description of riddles was already a major topic in verbal art research at the end of the $19^{\text {th }}$ cent. ${ }^{15}$ Although several riddle corpora from all parts of the world exist, there is no single generally accepted definition of the genre of riddle. An often-quoted and modified definition goes back to R. Petsch at the end of the $19^{\text {th }}$ cent. It involves a structural description of riddles encompassing not only the plain riddle per se but also introductory and concluding frames. ${ }^{16}$ The framing of a riddle is said to be of special importance only for African languages, while in most other riddle

\footnotetext{
${ }^{11}$ Cf. SHACK 1966.

${ }^{12}$ Cf. Markakis 1998.

${ }^{13}$ I refer to a working definition of culture which is currently used in the SFB 295.

${ }^{14}$ Harries 1971:377.

${ }^{15}$ For an overview see Evans 1976:166ff or HAMnETT 1967:379ff.

${ }^{16}$ For a critical summary of Petsch's work see GEORGES — DundEs 1963:111.
} 
corpora (e. g., English or Finnish) it either does not exist or is only an optional stylistic device. ${ }^{17}$ Thus, the plain riddle has been the main focus of attention. Consequently, definitions of riddles concentrated only on ambiguities originating out of metaphors or the presence of contradictory expressions. ${ }^{18}$ Later, however, riddles without contradicting expressions came into consideration, yielding the following definition:

«...[T]he riddle has been defined as a traditional verbal expression which contains one or more descriptive elements, a pair of which may be in opposition; the referent of the elements is to be guessed. Two general categories of riddles are (1) nonoppositional, in which there is no contradiction to be found [...], and (2) oppositional, in which at least one pair of descriptive elements is in contradiction. The nonoppositional riddles may be literal or metaphorical [...] Oppositional riddles are almost always metaphorical or a combination of metaphorical and literal descriptions». ${ }^{19}$

The metaphor is, thus, the main point of interest in non-literary riddles, which are also called true riddles. According to Maranda metaphors are semantic interpretations of certain concepts based on a set of cultural (or better cognitive) rules, which may differ considerably among several communities. ${ }^{20}$ Lieber modifies Maranda's approach in the direction of a semantic analysis and states:

«...the true riddle is a semantic game that manipulates the properties of objects, categories, and classes. The game is played at the level of signification of the semantic system of the language». ${ }^{21}$

Lieber distinguishes three different semantic levels: signification, denotation and connotation. The level of signification involves the defining properties for items or classes in the real and social world. When several properties are tied together they may represent natural or social constructions which get a linguistic realization as word or phrase on the level of denotation. A denotatum may have connotations of certain qualities. A true riddle, thus, consists of a denotatum, in the form of a metaphor, with additional descriptive properties from the signification level. Significantly, the denotatum and the additional properties seem to contradict each other. This contradiction emerges because the additional properties are not inherent to the class described by the denotatum. The riddle solver, therefore, has to rearrange certain properties of the denotatum in order to get the answer of the riddle. ${ }^{22}$

\footnotetext{
${ }^{17}$ George — Dundes 1963:113; Harries 1971:380, 383; Maranda 1976:133.

${ }^{18}$ Cf. George — Dundes 1963:111; Harries 1976:325.

${ }^{19}$ Georges - Dundes 1963:116.

${ }^{20}$ Maranda 1976:130.

${ }^{21}$ LIEBER 1976:261.

${ }^{22}$ LIEBER 1976:259f.
} 
Green and Pepicello (1984) make a new distinction regarding the source of ambiguity in a riddle. They distinguish metaphorically and grammatically based riddles. While metaphorically based riddles use ambiguities arising from cultural categories or constructions, grammatically based riddles represent ambiguities in the phonology, morphology, and/or syntax of the language system..$^{23}$ This is a very important distinction because it implicates that language and culture have to be treated separately. There are cases where one culture may contain several languages and vice versa.

It is also common sense that the social environment is tightly connected to the content of riddles. ${ }^{24}$ People not belonging to a given culture, therefore, may not understand the meaning of its riddles without an explanation. ${ }^{25}$ When a culture or society changes due to social and socio-economic circumstances, the content and the function of riddles will change, too. Maranda states, for instance, that the riddle in Finnish has lost its popularity and its social function due to modernization processes like increasing literacy and spread of mass media. ${ }^{26}$ Many scholars also believe that riddles are more productive and have a wider range of functions in non-literate societies. ${ }^{27}$ Probably the different status of riddles in literate and non-literate societies affects the process of learning or creating riddles. Maranda, who deals with Finnish riddles, describes riddling as a process in which the riddle poser uses his cognitive abilities to create new riddles or to react to a new environment. ${ }^{28}$ Other authors, ${ }^{29}$ however, describe riddling not as an active cognitive procedure but as memorization, arguing that very often only one traditionally or culturally sanctioned answer is accepted as the solution of a riddle even if other alternative answers also fit. Green and Perpicello combine both approaches. According to them children first learn culturally sanctioned riddles and reproduce them. Only when the corpus of traditional riddles is exhausted are new riddles invented. ${ }^{30}$ The invention of new riddles, according to Lieber, combines known structures of riddling with new concepts:

«[A riddle] serves to structure change by incorporating new categories and new properties into the existing set, and by relating new categories and new properties to old ones in its usual process of teasing apart and recombining properties». ${ }^{31}$

\footnotetext{
${ }^{23}$ Green - Pepicello 1984:201.

${ }^{24}$ Green - Pepicello 1984:191; Hamnett 1967:379; Lieber 1976:262; MaranDA 1976:128.

${ }^{25}$ HARRIES 1976:324.

${ }^{26}$ MaRANDA $1976: 128$.

${ }^{27}$ Cf. Harries 1971:378; Maranda 1976:128.

${ }^{28}$ Maranda 1976:131.

${ }^{29}$ Cf. Hamnett 1967:385; Harries 1976:320.

${ }^{30}$ Green - Perpicello 1984:192.

${ }^{31}$ Lieber 1976:263.
} 
The incorporation of new categories and properties into existing structures may trigger a change of these structures and the loss of old metaphors. However, reanalysis of old constructions towards a new denotatum will in turn produce new metaphors. A characteristic feature of this changing process is the existence of more than one correct answer to a riddle within the cultural and social background of the riddlers.

The study of the riddle in Ethiopian languages started ${ }^{32}$ with Mittwoch, to the best of my knowledge. Mittwoch's article provides 10 riddles in Amharic with a translation into German with additional remarks on linguistic phenomena. ${ }^{33}$ Later Leslau presents a very impressive collection of riddles in several Gurage languages. The riddles are translated into English with annotations regarding grammatical forms and, less often, cultural phenomena. The main focus is on the linguistic, not on the cultural, interpretation of the riddles. ${ }^{34}$ A thorough study of riddles in Oromo has been done by Tamene Bitima. He lists more than eighty riddles in Oromo with an English translation and gives additional information on the riddling process, i. e. the cultural background of riddling. ${ }^{35}$

\section{Riddles in Muher, Wolane and Zay}

In the following section I will concentrate mainly on my own riddle collections in Muher, Wolane and Zay, ${ }^{36}$ i. e. Ethiosemitic languages for which no riddle corpus has been published so far.

\section{Formal observations}

Among the Muher, Wolane and Zay, riddles are used for entertainment and also for educational purposes among youngsters. Older men and women know riddles but usually do not pose them freely. To the best of my knowledge, there are no riddle sessions lasting for an hour or so as described by Evans. ${ }^{37}$ The main occasions for riddling are the early evening hours when day's work has been done, during coffee ceremonies or other informal meetings or while breeding cattle.

${ }^{32}$ I consider here only bilingual works with English or German as metalanguage for explaining/translating the riddle corpora. Beside these works there are many monolingual riddle collections in the respective languages and bilingual riddle collections with Amharic as metalanguage (cf. among others ZäRIHUN AsFAW 1992:38ff. and 69f.), which are not easily accessible.

${ }^{33}$ Mittwoch 1907:209ff.

${ }^{34}$ LeSLau 1965; 1967/68; 1982.

35 TAMENE Bitima 2004.

${ }^{36}$ The riddles were collected during my linguistic field researches on Gurage languages from 1998 through 2004.

${ }^{37}$ Evans 1976:171ff. 
In all three languages - Muher, Wolane and Zay — the riddle is a special text genre with a similar structure consisting of three parts: i. introductory frame; ii. plain riddle; iii. concluding frame.

In the introductory frame one of the riddlers signals by a formal phrase that he intends to pose a riddle. When another riddler is ready to solve the riddle he will agree, again using a strict formula (cf. Appendix I). These formulas are repeated with every new riddle. After the introductory frame the plain riddle follows. When the riddle-solver knows the right answer the concluding frame is quite short. The riddle poser acknowledges that the riddle is solved using the formula «You know it!» The riddle solver or another person can now take his turn and pose a new riddle. In the case the riddle was not solved another common routine for giving the solution exists. The riddle poser first asks for a place name (village or town). Then the riddle solver starts to enumerate several places. Normally the riddle poser will not accept the first place and asks for more prestigious places. A place can be given only once during a riddle session. When the riddle poser has chosen a place of his convenience, which can take a certain amount of time, he recounts all the activities he intends to do at this place. In a joking manner he also may use these activities in order to insult the riddle solver (see examples in Appendix I). Finally, the riddle poser names the solution and the session continues with a new introductory frame. Every riddle is thus enclosed within a formal structure.

\section{Semantic and Cognitive Observations}

Riddles can be classified according to the semantic field described by the answer, ${ }^{38}$ as has been done in Appendix II. The following semantic groupings were found: house and household utensils, working tools and places (outside the house), food, body parts, animals and plants, nature and others. Although the collected riddle corpora are very small and differ in number, the majority of riddles deal with items from the house and household utensils, followed by riddles dealing with nature, animals and rarely plants. Body parts are quite an unusual topic.

According to Georges and Dundes, there are two basic semantic differences in the content of the riddle: A riddle can either be oppositional or nonoppositional. Among nonoppositional riddles there are literal or metaphorical riddles. Literal riddles consist simply of a wh-word question, with the wh-word itself refering to the answer of the riddle. ${ }^{39}$

Almost all riddles in Muher, Wolane and Zay are based on metaphor; only one literal riddle was found in the Wolane example (56). Although there exist nonoppositional riddles they are relatively few. Good examples for nonoppo-

\footnotetext{
${ }^{38}$ Cf. Maranda 1976:135.

${ }^{39}$ GeORgES — Dundes 1963:113ff.
} 
sitional riddles are examples (7), (9), (10), (14), (20) for Muher; (33), (40), (43), (45), (50), (55), (56), (60) for Wolane and (68) for Zay. The majority of the riddles, however, involve metaphorical expressions with an opposition. Most of them contain a proposition followed by a further comment or modification which seems to be contradictory to the proposition, i. e. (2), (4), (15) for Muher; (23), (36), (57) for Wolane and (64), (66), (69) for Zay. Riddles consisting of a proposition followed by more than one modification are rare. They appear only in Wolane (33), (42), (53) and all involve nonoppositional metaphors.

Thus, the main vehicle for posing a riddle in Muher, Wolane and Zay is the metaphor. There are no grammatically based riddles which appeal to ambiguities of the language system. Although the corpora are very limited there are cases where the riddle-answer in different languages coincides. Some riddles use the same metaphors although they belong to different languages. Almost identical are the Muher and Wolane metaphors for coffee pot and coffee cups which are the central utensils of the coffee ceremony in every Gurage house. The coffee pot is always black and made of clay; the coffee cups are mostly white. The respective metaphors, riddles (6) and (26), refer to the coffee pot as mother and to the cups as children. A contradiction arises due to the naming of the respective colors. A similar metaphor of mother and child is used when referring to the traditional mill in Wolane and Zay, as can be seen from riddles (25) and (65). This mill consists of a large, fixed stone at the bottom — the mother — and a small, movable stone — the child — for grinding the crops. The mother is also a metaphor in riddles (13) for Muher and (51) for Wolane, here referring to the earth. A traditional woman's garment consists of a dress which is tied by binding a long narrow belt made from cotton several times around the hips. This belt is the metaphor for the term way, which also has no apparent starting and ending point. Very similar are the metaphors for an obstacle in Muher (12) and Wolane (55). Both languages indicate that an obstacle may damage the skin of a foot like the skin of onions when peeled or like crops in a mill when crashed. The idea that something is thrown away in the morning and taken up in the evening is used to refer to a rope for tying cattle inside the house. In the morning, cattle are taken away and the rope with which they have been tied is thrown onto the ground. In the evening, when they return, the rope is taken up again for tying them up.

Different metaphors for the same denotatum may appear across several languages, as well as within a single language. Thus, we find different metaphors for fire of a fireplace in Muher (3) against Wolane (21), for door of a house in Wolane (31) and (32) against Zay (67), and for butter in Wolane (39) and (40) against Zay (67). Wolane speaker very often can use different metaphors to refer to a single denotatum, e. g., riddles (22) and (23), which both refer to the small hole of a fire place inside the house, riddles (31) and (32), 
referring to a door, riddles (39) and (40), referring to butter and riddles (43) and (44) referring to an ant. The reverse case, where one metaphor refers to two denotata, also appears as in Muher riddle (3) or in Wolane (58).

Although the riddle corpora in Muher, Wolane and Zay are quite limited, they show that these languages use an identical mechanism for posing riddles. Surprisingly, there are also numerous cases of identical metaphors used by speakers of two separate languages to refer to the same denotatum.

\section{Linguistic observations}

While Muher $ə n q^{w} i t$ and Wolane $w u n q^{w} i t$ are used to express the concept «riddle», we find the term hibbo in Zay. The term * $(w) ə n q\left({ }^{w}\right) i t$ appears, furthermore, in all Gurage languages except Zay. Leslau proposes a Cushitic origin for this term and compares it with Kabeena $u n q^{w} \bar{t} t a$ and Alaba yūnqi$t i{ }^{40} \mathrm{He}$ also mentions the possibility that there might exist a connection to

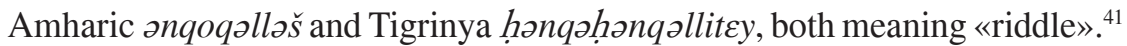
The Zay lexeme hibbo seems to be of Cushitic origin connected with Sidaama hibbó and with Oromo hibbo. ${ }^{42}$

Kabeena and Alaba are closely related Highland East Cushitic languages which are spoken in areas adjacent to the Gurage. Based on oral traditions from the Gurage region and the reconstruction of the sociolinguistic environment and mechanism in the language contact situation between Kabeena and Wolane, ${ }^{43}$ it appears highly improbable that the majority of the Gurage languages borrowed the lexeme $*(w) \approx n q\left({ }^{w}\right) i t$ from either Kabeena or Alaba. The main reason for this conclusion is that Kabeena and Alaba people may speak Gurage languages but Gurage people usually do not know Kabeena or Alaba. Highland East Cushitic languages are of very low prestige among Gurage speakers. Furthermore, the Kabeena migrated towards their present living place relatively late, in the $19^{\text {th }}$ cent., so that it is quite unlikely that they had such an impact on the Gurage languages. This is also indicated by the fact that other Highland and Lowland East Cushitic languages use the term hibbo. I would propose, therefore, a different etymology for the term $*(w) \partial n q\left({ }^{w}\right) i t . \mathrm{G}^{c} \partial \mathrm{z}$ roots beginning with a glottal or pharyngeal consonant (stop or fricative) often have cognates in East Gurage languages beginning only with a glottal stop. In addition they possess an inserted nasal $n$ just in front of the second radical. ${ }^{44}$ The Gurage term *(w) an $q\left({ }^{w}\right)$ it may, thus, represent a reconstructed root consisting of a glottal stop emerging from a pharyn-

\footnotetext{
${ }^{40}$ LeSlau 1979a:512; 1979b:72.

${ }^{41}$ Leslau 1979b:72.

${ }^{42}$ LeSLAU 1979b:231.

${ }^{43}$ For the oral traditions see among others CRASS - MEYER 2001:176. A language contact situation in between Kabeena and Wolane is described in CRASS - MEYER 2005.
}

${ }^{44}$ Cf. Hetzron 1969; 1972:42. 
geal fricative, a labial element and the ejective plosive $q$. Such a root in fact

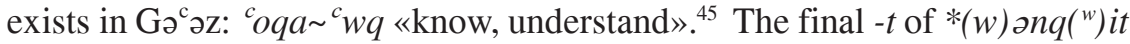
as well as the vocalization pattern may represent a Semitic template for nominals.

In the verbal domain of Gurage languages, too, we find a root $* \sqrt{n-q}$ which also may be connected to $*\left({ }^{c} / w\right) n q>* n q$ «to know, to understand». Words built from the root $* \sqrt{n-q}$ survive only as special imperatives $n \partial^{\circ} \partial$ (masc.) / $n \curvearrowright q^{j}$ (fem.) «what shall I know for you (masc./fem.)» in Muher and $n u^{\circ}$ (masc.) / $n u^{\circ} i$ (fem.) in Wolane. These imperatives are restricted to the introductory frame of riddles; they do not appear in other contexts or paradigms. This means that different nominal and verbal forms of a lexeme referring to the semantic concept of knowing or understanding appear in the introductory frame. The semantic interpretation of the root $* \sqrt{n}-q$ would fit into the Amharic riddle

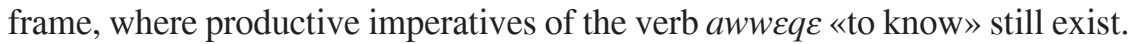
There is, however, one problem with this reconstruction. The imperatives behave like biradical verbs. The nasal element $n$, therefore, must be considered a true radical assuming its own position in the root, and is thus not an adjunct to the second radical as was proposed above. This may suggest either that the nasal element was reanalyzed from a kind of epenthetic consonant to become a true radical, or that the root is, after all, not cognate with $\mathrm{G} \partial^{c} \partial \mathrm{z}{ }^{c} o q a \sim^{c} w q \ll \mathrm{know}$, understand». In the latter case there is a further possible candidate for the origin of the root $* \sqrt{n-q}$ or even $*(w) \partial n q\left({ }^{w}\right) i t$. It may be represented by the Gə ${ }^{c} \partial \mathrm{z}$ interjection ${ }^{c} \partial n q^{w} \bar{a}^{c}$ «aha!, bravo! well now, hurrah! hail!» ${ }^{46}$ In East Gurage languages the glottal stop and the pharyngeal fricative would disappear diachronically. What remains then is a root $* \sqrt{ } n-q-a$, the pharyngeal fricative having left its trace in a vocalic radical. Semantically a kind of imperative would fit better into the introductory frame of Muher and Wolane because the riddle solver's utterance is more an exclamation than a true question.

To refer to the verbal expression «to riddle», a compound consisting of the noun for riddle and the verb for «to tell» is used in most of the Gurage languages. ${ }^{47}$ This may indicate that the lexeme $*(w) \partial n q\left({ }^{w}\right)$ it should be considered a loan or at least an archaic form in the Gurage languages. It is not an indigenous or productive root from which verbal forms may be built according to the common root and vowel pattern. Leslau proposes a Cushitic origin for the root $* \sqrt{ }^{c} o q a \sim^{c} w q$ and provides examples from Agaw and Somali. ${ }^{48}$ Whatever the origin of the term $*(w) \partial n q\left({ }^{w}\right)$ it and its derivations, it is clear that it has taken on a very specific meaning in the Gurage languages, surviving only in the introductory frame in riddles and nowhere else.

\footnotetext{
${ }^{45}$ LeSLAU 1991:78.

${ }^{46}$ LeSLAU 1991:31.

${ }^{47}$ LeSLAu 1979a:512.

${ }^{48}$ LeSLAu 1991:79.
} 
The productive verb for «to know/to experience», going back to a root $* k h l,{ }^{49}$ is used in the concluding frame of riddles in all Gurage languages including Zay. This verb appears uniformly in the perfective aspect in all languages. If the riddle solver does not know the solution to the riddle, complex sentences with converbs are used quite frequently for mocking.

Regarding the grammatical form of the verbs involved in riddles, it seems that perfective and imperfective verbs appear quite often but the perfect and jussive are rarely used. In the corpus the perfect appears only in the Wolane example (51), and the jussive in examples (25) and (58) for Wolane and (65) for Zay. Furthermore, one gets the impression that there is a tendency to prefer imperfective verb forms. Although both perfective and imperfective verbs appear with equal frequency in Muher, in the few Wolane and Zay riddles the imperfective seems to be the preferred verb form.

Very often the riddles in Muher and Wolane but not in Zay are represented by an elliptic sentence, with the main clause missing (cf. Muher (1), (6), (8), (9), (15), (16) and Wolane (21), (22), (26), (28), (29), (31), (32), (33), (34), (35), (41), (43), (45), (46), (47), (48), (49), (59). In these sentences a whphrase meaning «... - What is it?» could have been added, as is the case in (20) for Muher or (53) for Wolane.

Specific concepts expressed by ideophones, which appear more or less frequently in everyday speech, are quite rare, as in Muher (1), (15), (19), (20) and Wolane (22), (23), (33), (58). Furthermore, grammatically based riddles seem not to exist in Muher, Wolane and Zay. This result is very surprising because grammatically based metaphors are a very common literary device in Amharic called semənna werq «wax and gold». ${ }^{50}$ It seems that a main factor for grammatically based metaphors is the existence of a script and a writing tradition. While Amharic has been written for several centuries, Muher, Wolane and Zay are only used for oral communication until today.

The above discussion shows that linguistically riddles employ a quite simple grammar, and focus mainly on the semantic content of a metaphor. Redundant information, even a verb, may be omitted. Most divergent among the three Gurage languages is Zay. It uses different terms in the introductory frame, and there are a number of Zay riddles which either consist of a mixture of Zay and Oromo, e. g. riddle (68), or are purely Oromo, like riddles (67) and (70). A very strong tendency to use either the Oromo or Amharic language for oral art can be observed in Zay.

\footnotetext{
${ }^{49}$ LeSlau 1991:277.

${ }^{50}$ Cf. RICHTER 1993; 2002.
} 


\section{Conclusion}

In this article I have dealt with riddles from three different Gurage languages - Muher, Wolane and Zay — which have many features in common. In all three languages and even in the contact languages Amharic and Oromo the plain riddle is embedded in a strict frame which has the same structure in all the languages. The introductory frames in Muher and Wolane even use the same lexical expressions, which may also be cognate with Amharic. Furthermore, Muher, Wolane and Zay use only metaphors as a riddling device. These metaphors are expressed through a minimal set of grammatical forms and refer most often to objects of the house(hold), food, and nature, i. e. items that are important for everyday life. Riddles based on language ambiguities or on specific language expressions like ideophones either do not exist or are very rare.

This situation seems to fit a multilingual community where the speakers are familiar with several languages. Here two phenomena can be observed. On the one hand, speakers of different languages use the same cognitive constructions (i. e. metaphors) and grammatical realizations to refer to a denotatum but express it in their respective languages. On the other hand, different cognitive constructions for a single denotatum coexist in the same language. Social constructions (culture) and languages have begun to converge. It remains open, however, when and from which particular language or culture these processes originated. It is only possible to state that riddle frames and the riddling mechanisms are quite similar among the Gurage languages in question, and also in Amharic and Oromo. Common features among different languages without information about their origin is in fact one main feature of a language convergence area. ${ }^{51}$

Riddles in Zay are of special interest in this case. Although Zay and Wolane are closely related genetically, they use different linguistic realizations in the introductory frame. While Wolane makes use of the same language material that appears in other Gurage languages, Zay shows a clear Oromo influence. Not only the introductory frame is borrowed from Oromo, even the riddles themselves are posed fully or partly in Oromo instead of Zay. This may indicate that riddles are not the result of an active cognitive procedure of the speaker but a memorization process of social norms and their linguistic realization.

When in a geographic area like the Gurage region several communities have intensive contact over a long time, they may develop a kind of a common culture of contact, i. e. contact-induced communicative processes that result in similar social constructions of reality and even in similar cultural expressions. The end and the starting point of these processes remains, however, a riddle.

${ }^{51}$ Cf. Thomason 2001:89. 


\section{Bibliography}

BraukäMPER, U. 1980. Geschichte der Hadiya Süd-Äthiopiens. (Studien zur Kulturkunde, 50), Wiesbaden: Franz Steiner Verlag.

Chernetsov, S. B. 1980. «Zu den Veränderungen der gesellschaftspolitischen Lexik in der mordernen amharischen Sprache und der Sprachsituation im revolutionären Äthiopien». In: Olderogge D. A. — Brauner, S. (eds.) Sozialer Wandel in Afrika und die Entwicklung von Formen und Funktionen afrikanischer Sprachen. (Linguistische Studien Reihe A, Arbeitsberichte, 64), Oberlungwitz: Akademie der Wissenschaften der DDR, 120-143.

Crass, J. - Meyer, R. 2001. «The Qabena and the Wolane: Two peoples of the Gurage region and their respective history according to their own oral traditions». AÉ 17:175-182.

Crass, J. - Meyer, R. (2005). «Die Komplexität sprachlicher und kultureller Kontakte anhand der Nomenklatur zur Ensete-Pflanze». In: Bisang, W. — Bierschenk, T. - Kreikenbom, D. - Verhoeven, U. (eds.) Kulturelle und sprachliche Kontakte. Prozesse des Wandels in historischen Spannungsfeldern Nordostafrikas/ Westasiens. Akten zum 2. Symposium des SFB 295 der Johannes GutenbergUniversität Mainz, 15.-17.10.2001. Würzburg: Ergon Verlag, 411-427.

Evans, D. 1976. «Riddling and the structure of context». The Journal of American Folklore 89 [352]: 166-188.

Fergusson, Ch. A. 1976. «The Ethiopian language area». In: Bender, M. L. et al. (eds.) Language in Ethiopia. London: Oxford University Press, 63-76.

Georges, R. A. - Dundes, A. 1963. "Toward a structural definition of the riddle». The Journal of American Folklore 76 [300]: 111-118.

Green, Th. A. - PePicello, W. J. 1984. «The riddle process». The Journal of American Folklore 97 [384]: 189-203.

Haberland, E. 1963. Galla Süd-Äthiopiens. (Völker Süd-Äthiopiens. Ergebnisse der Frobenius-Expeditionen 1950-1952, 1954-1956, Band II) Stuttgart: Verlag W. Kohlhammer.

Hammerschmidt, E. 1967. Äthiopien. Christliches Reich zwischen Gestern und Morgen. Wiesbaden: Otto Harrassowitz.

HamnetT, I. 1967. «Ambiguity, classification and change: The function of riddles». Man (New Series) 2, 3: 379-392.

HARrIES, L. 1971. «The riddle in Africa». The Journal of American Folklore 84 [334]: 377-393.

HARries, L. 1976. «Semantic fit in riddles». The Journal of American Folklore 89 [352]: 319-325.

HAYWARD, R. J. 2000. «Is there a metric for convergence?» In: Renfrew, C. McMahon, A. - Trask, L. (eds.) Time depth in historical linguistics, vol. 1, Cambridge: McDonald Institute for Archaeological Research, 621-640.

Hetzron, R. 1969. «Two notes on Semitic laryngeals in East Gurage». Phonetica 19: 69-81.

Hetzron, R. 1972. Ethiopian Semitic. Studies in classification. (Journal of Semitic Studies Monograph No. 2) Manchester: Manchester University Press. 
Hetzron, R. 1977. The Gunnän-Gurage languages. (Richerche. Studi di Semitistica e del Vicino Oriente Antico, 12) Napoli: Istituto Orientale di Napoli.

Huntingford, G. W. B. 1955. The Galla of Ethiopia. The kingdoms of Kafa and Janjero. (Ethnological Survey of North-East Africa, 2) London: International African Institute.

LeSLAu, W. 1945. «The influence of Cushitic on the Semitic languages of Ethiopia. A problem of substratum». Word 1, 1: 59-82.

Leslau, W. 1952. «The influence of Sidamo on the Ethiopic languages of Gurage». Language 28, 1: 63-81.

LESLAU, W. 1965. «Chaha riddles». RSE 21: 27-93.

LESLAU, W. 1967/68. «Ežha riddles». RSE 23: 43-78.

Leslau, W. 1979a. Etymological dictionary of Gurage (Ethiopic). Vol. II: English-Gurage Index. Wiesbaden: Otto Harrassowitz.

Leslau, W. 1979b. Etymological dictionary of Gurage (Ethiopic). Vol. III: Etymological Section. Wiesbaden: Otto Harrassowitz.

LESLAU, W. 1982. Gurage folklore: Ethiopian folktales, proverbs, beliefs, and riddles. (Studen zur Kulturkunde, 63), Wiesbaden: Franz Steiner Verlag.

Leslau, W. 1991 [repr. of 1987 edition]. Comparative dictionary of $G e^{c} e z$ (Classical Ethiopic). Wiesbaden: Otto Harrassowitz.

Levine, D. N. 1974. Greater Ethiopia. The evolution of a multiethnic society. Chicago and London: The University of Chicago Press.

LIEBER, M. D. 1976. «Riddles, cultural categories, and world view». The Journal of American Folklore 89 [352]: 255-265.

MARANDA, E. K. 1976. «Riddles and riddling: An introduction». The Journal of American Folklore 89 [352]: 127-137.

Markakis, J. 1998. «The politics of identity. The case of the Gurage in Ethiopia». In: Mohamed Salih — Markakis, J. (eds.), Ethnicity and the state in East Africa. Uppsala: Nordiska Afrikainstitutet, 127-146.

Meyer, R. - RichteR, R. 2003. Language use in Ethiopia from a network perspective. Frankfurt am Main: Peter Lang Verlag.

Miтtwoch, E. 1907. «Proben aus amharischem Volksmunde». Mitteilungen des Seminars für Orientalische Sprachen an der Königlichen Friedrich-WilhelmsUniversität zu Berlin, 10: 185-241.

Pankhurst, S. 1955. Ethiopia. A cultural history. Essex: Lalibela House.

Richter, R. 1993. «Wachs und Gold in der äthiopischen Dichtung». In: Möhlig, W. J. G. - Brauner, S. — Jungraithmayr, H. (eds.), IX. Afrikanistentag Beiträge zur afrikanischen Sprach- und Literaturwissenschaft, Leipzig, 24.26. September 1992. Köln: Rüdiger Köppe Verlag, 277-284.

RichteR, R. 2002. «Wenn das Wachs schmilzt...» In: Arnold, W. — Bobzin, H. (eds.) «Sprich doch mit deinen Knechten aramäisch, wir verstehen es!» $60 \mathrm{Bei}$ träge zur Semitistik. Festschrift für Otto Jastrow zum 60. Geburtstag. Wiesbaden: Otto Harrassowitz, 569-582.

Shack, W. A. 1966. The Gurage. A people of the Ensete culture. London et al.: Oxford University Press. 
Tamene Bitima. 2004. «Oromo riddles». In: Griefenow-Mewis, C. — Tamene Bitima (eds.) Oromo oral poetry - seen from within. Köln: Rüdiger Köppe Verlag, 81-91.

Thomason, S. G. 2001. Language contact. An introduction. Edinburgh: Edinburgh University Press.

Thomason, S. G. - Kaufman, T. 1988. Language, contact, creolization, and genetic linguistics. Berkeley et al.: University of California Press.

Tosco, M. 2000. «Is there an "Ethiopian language area"?» Anthropological Linguistics 42, 3: 329-365.

UllendorfF, E. 1960. The Ethiopians. An introduction to country and people. London: Oxford University Press.

Zärihun Asfaw. 1992 Eth.Cal. Yäsənäş̧huf mäsärätawəyyan. Addis Abäba: Nəggəd Mattämiya Dərəğğət [Amharic].

\section{Appendix I: Riddle frames}

In the appendices I have tried to keep close to the original languages with the English translation. However, in many examples the translation represents only a rough idea of the concept expressed in the source language. The language examples are transcribed according to the respective utterances without indicating morpheme breaks or assimilations. ${ }^{52}$

Riddles were recorded, transcribed and translated together with TEMESGEN Wolde Medhin (1998/99; Zway) for Zay, with SHAmIL SAYYID (2000/01, Wolkite) for Wolane and with AbUbaKR SHERIfo (2004; Wolkite) for Muher. The riddle structure for Amharic were discussed with Samira Amsalu (2003; Wolkite) and for Oromo with Samuel Adola and Dabala Goshu (2003; Jimma and Addis Ababa). I am also indepted to Aman Kedir Kamsare (Troms $\varnothing$, 2003), who provided me with an Oromo riddle from the Zway area.

\section{Amharic}

Introductory Frame.
A: ənqoqqวləš! $!^{53}$
Riddle!
B: mon awqallah (masc. A)! / What shall I know for you! mən awqalləš (fem. A)!

Concluding Frame.

When B knows the solution of the riddle:
A: awweqkew!
You know it!

When B does not know the solution of the riddle:

A: alawweqkewm! ager soteñ̃ñ! You (mas) do not know it! Give me a place!

B: ambo. Ambo.

52 The following abbreviations are used: $\mathrm{A}=$ riddle poser, $\mathrm{B}=$ riddle solver.

53 Amharic either uses onqoqqələš for both males and females, or has onqoqqələh for male and ənqoqqələs̆ for female riddle solver. 

A: alfellogəmm.
I do not like it!
B: gonder.
Gondar.

...

\section{Muher}

Introductory Frame.
A: $y \varepsilon h \partial n q^{w} i t !^{54}$
Take a riddle!
B: $n \partial^{\circ} \partial$ (masc. A)! /
$n \partial q^{j}$ (fem. A)!
(What shall I know for you!)

Concluding Frame.

When B knows the solution of the riddle:
A: hehennวm!
You know it!

When $\mathrm{B}$ does not know the solution of the riddle:
B: annəçin.
I don't know it.

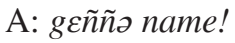

Give me a country/place!

B: welqite.

Wolkite.

A: bennahuwem!

I ate at this place!

B: jimma.

Jimma.

A: yehun, jimma nəbiyawe, nəstewe! All right, I shall eat and drink in befur teməq ${ }^{j} m \partial q^{j} \varepsilon$ tangačča yeçani Jimma! May one load your stuff yedehe. bawroplan temekina yečani yedi! nōthe? at a mouse, a skunk and a cat! May one load my stuff at an airplane and a car! Shall I tell you?

B: oy! Yes!

A: [solution] ...

\section{Wolane}

Introductory Frame.
A: $n \varepsilon$ (masc.) / ney (fem.) wunqwit!
Come a riddle!
$\mathrm{B}: n u^{\circ}$ (masc.)! /
What shall I know for you! $n u^{\circ} i$ (fem.)!

When B does not know the solution of the riddle:
A: gebiye wābeñ!
B: ğimme gebiye wused!

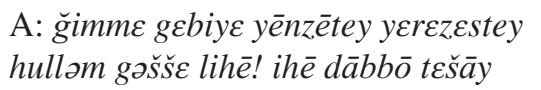
tilbel — ' at yebučō quzān ble!
ihe bayer tilhēd - ${ }^{\circ} a t \varepsilon$ bimwār
tesc ${ }^{\circ} \varepsilon l \varepsilon$ hid! melsi ...!

Give me a market!

Take Jimma market!

All things that can be found at Jimma market are for me! While I am eating bread with tea - eat the shit of a dog! While I am traveling by air — travel at the back of a donkey! The answer ...

${ }^{54}$ This phrase consists of the irregular imperative $y \varepsilon h \varepsilon$ «here, take it (mas.)» and the noun $ə n q^{w} i t$ «riddle». 


\section{Zay}

Introductory Frame.
A: hibbō!
Riddle!
B: hibib!
What shall I know for you!

Concluding Frame.

When B knows the solution of the riddle:
A: čālhenu!
You know (it)!

When B does not know the solution of the riddle:
A: alčaləho - debər ābeñ
You do not know it - give me a country!

B: aburān nəqعl!

A: hīd, alfāç̌u abūrān!

Take Abura!

B: adāmān nəqعl

Hey, I don't like Abura!

A: nāzrēt yəgebām befōqi yəncbərəm Take Adama!

ketemāy seffīnu. yəzāborəm bebisklēt

After I entered Nazreth ${ }^{55}$ I will live yəhīdəm šāyi yəseč yəgebām tēp yūhəbəm bemusiqāy in a skyscraper and the town is big. yəffīqerəm - benāzrēt yəggūbāx būytənu. lēdāx melsey? I will go for a walk and ride a bike, I will drink tea, enter my house every evening, buy a tape, dance to the music - that means that I am living (lit. sitting) in Nazreth. Shall I tell you the answer?

\section{Oromo}

Introductory Frame.
A: Hibbo!
B: Hib/Hibbak(a)/Hibiriq/Hibibi!
Riddle!
Ask!

TAMENE Bitima (2004:81) contains many examples for Oromo riddles. What is important here is the answer hibibi, which seems to be a special variant found only around Lake Zway (personal communication AMAN KEDIR in 2003). This form was most probably transferred into Zay as hibib.

\section{Appendix II: Riddle Corpora}

\section{Muher Riddles}

\section{House and household utensils}

(1) besečča buqq, bebar dəmbuqq? ${ }^{56}$ Outside very big, in a river (sinking sound)?

${ }^{55}$ Adama and Nazreth are the respective Oromo and Amharic namings denoting the same town.

${ }^{56}$ The words buqq «big thing» and dəmbuqq «sound referring to big object that sink into the water» are ideophones. 
wešદn.

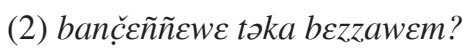

weggən.

(3) arreçim ererreçim begbattəhut werq arreçim?

osat wem fem.

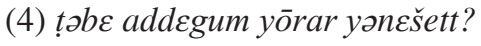

yənnam wederen.

(5) yōrar yadgwitt. tobe yənešett?

ǧวbben.

(6) adotwe to ${ }^{\circ} u r$, deng $^{j}$ awe $g^{w}$ ad $g^{w} a d$ ?

$$
\text { ǧcbenam sinəmmən. }
$$

\section{Working tools and places}

(7) beduwe ēbelo bęcm yəțero? weyse.

(8) әmmet $y \varepsilon t^{w}$ oannemabb ${ }^{w} \varepsilon$ meder - mult?

ti $i^{\circ}$ ot yet $t^{w}$ oannawe mederən.

\section{Food}

(9) bef we g'ad amora? $n \varepsilon^{\circ} \varepsilon b a$.

(10) $h^{w}$ ettwe gebsya lahuycmum, attwe bet to ${ }^{\circ}$ ore?

bet $t \partial^{\circ}$ orewe angubaya.

gebeya yəleh wyemwe qəbəm $n \varepsilon^{\circ}$ ebamnom $^{w}$.

\section{Nature}

(11) țbe ažžchunnəm.

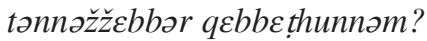

$a w \varepsilon$.

(12) әnəssiye gered bezeba twoannattom wefičç̌ tof\&çi?
Water container made from clay. Although not giving birth he has a lot of children?

Small wooden supports around the central pillar.

One cut it and cut it into little pieces and cut gold in the middle?

Fire or embers.

One threw it in the morning and picked it up in the late afternoon?

Rope for tying up a cow.

One throws it in the late afternoon.

One picks it up in the morning?

Mat made of fiber used for sleeping.

The mother black, the children white?

Coffee pot and cups.

He calls one from over there?

Axe.

The place at which the lady of the house is sitting — bald-headed?

The place at which the scratched parts of Ensete edulis is kept for a certain time.

On top a white large bird?

Cheese.

One sent two to the market, the other one watches the house?

The one who watches the house is whey.

Those that were sent to the market are butter and cheese.

I saw it in the morning. When I returned I missed it?

Dew.

A small female child makes flour with a mill, sitting on the way? 
onqurfit.

(13) yadoddi azgald bənnətagged

bənnətagged anne ${ }^{\circ}$ bęem?

zeban.

(14) bə̌̌šs ənnaməddi g ${ }^{w} a r r a ~ g{ }^{w} a r r a$ yəžarrəgu? $\partial m b^{w} \varepsilon^{j} \varepsilon n$.
Obstacle.

Although I tie the belt of my mother again and again it did not finish?

It is the way.

My red cow goes from garden to garden?

It is a torrent.

\section{Animals and Plants}

(15) gunnen gafgaff ${ }^{w} \varepsilon t$, Egər sibilləwet? A head very big, a leg very thin? ambin. It is cabbage.

(16) $b \varepsilon \check{c} \check{c} \check{c} \varepsilon f^{w} e s a m b{ }^{w} a$ ? č̀man.

(17) bira ṭere ${ }^{\circ}$ beqqęem? yənnam qerrən.

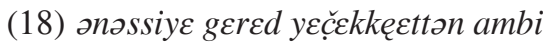
уəс̆̌mu?

$$
\text { nəb- wiye. }
$$

(19) ənəssiye gered bedbər $b^{w^{2}}$ nnattom $k^{w} a \check{s}$ təobiw?

qəme! On top of a pillar/tree a lung? Tapeworm.

Dry grew out of raw?

It is the horn of a cow. A cabbage prepared by a small female child is tasty?

Bee and honey. A small female child makes a rustling noise after she entered the wood?

Louse.

\section{Other}

(20) əzz bęzm - эnzəzz, aa bęem gamba $;{ }^{57} \mathrm{mo} e n$ ? qebrən.

It says zzz — a beetle, It says aa - a clay container; what is it? It is a grave.

\section{Wolane Riddles}

\section{House and household utensils}

(21) buš̨ burdō belegedō? gire.

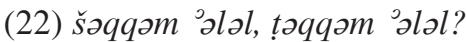

$$
\text { šsbrekō. }
$$

(23) $m \bar{o}^{\circ} \bar{e} t \varepsilon m \bar{o}^{\circ} \bar{e} t \varepsilon \check{s} \partial k k^{\circ} a t \partial l \bar{a} t$.

šcbrekō.

Red chopped meat in a hole?

Fire.

It does not come near and does not go away?

Fire place in a house.

She feels hotter and hotter but does not move?

Fire place in a house.

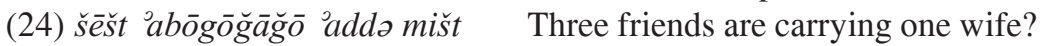
yətowruwān?

${ }^{57}$ The phrase a bęcm means «to open the mouth». 
gāwziyye..$^{58}$

(25) 'วndet lember lember, gered

lebrer lebrer?

wof çề $m \varepsilon \bar{g} \bar{e}$.

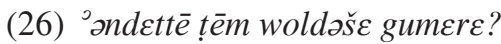

ğebenewe sin.

(27) gered lindešš təwo ${ }^{\circ} \bar{a} t$ ? meqetwe ${ }^{\circ}$ ont.

(28) țēm bāre bemāger? țābāt.

(29) $m w$ ālt mwālt bedeččé, ${ }^{\circ}$ arōt arōt begōteččēe?

yiri woderō.

(30) suuləm ’aywōçāan, deçç̌ēm `aywordān.

$q \overline{o t}$.

(31) bedehenō masket țāfōt?

wozgeb.

(32) mwālt mwālt rēse, ${ }^{\circ}$ arōt ${ }^{\circ}$ arōt qerēze?

wozgeb.

\section{Working tools}

(33) 'addi besār der zeff, ${ }^{\circ} a d d i$ bemey zeff, 'addi bebāhor zāf der $z \varepsilon f f$ ?

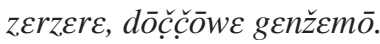

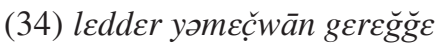

hulləm səntərāmče?

žāgbe.

(35) malt zāfte gō gebāt?

merfēwefctol.

(36) qell kelte gō feğ $\bar{e}$ ?

melāç.
The three fire stones for cooking. The mother (says) let's stay, let's stay, the female child (says) let's go let's go?

Big and small mill stone.

The mother is black and her children are white?

Coffee pot and cups.

A female child hits her mother?

Mortar and pestle.

A black ox at the wall?

A black clay plate.

At daytime on the ground, at nighttime on the shoulder?

Rope for tying a cow.

It does not climb the top and does not go down to the earth?

Sleeping platform on four poles inside the house or outside under the eaves.

A small piece of rug at the backside of a buffalo?

A door.

At daytime like a corpse, at nighttime like a youngster?

A door.

One sits on the grass, one sits in the water, and one sits in the eucalyptus tree?

Sickle, water container and axe. All female children who come from the top have a small space between their teeth?

Instrument for crushing the tube of the Ensete edulis.

It pulls a tapeworm and goes to the wood?

Needle and thread.

A small axe finished the wood?

Razor blade.

${ }^{58}$ There are always three supports made from clay arranged around a fire hole on which the cooking pot or plate rests. 
(37) bețoweruy rēsān, bencçuy wurbān?

bret.

\section{Food}

(38) yansuwe qerēze gār wōntiye derese?

šāmit.

(39) bibbimazer wo $^{\circ} i$ babbimazer wo $i$ mōfen atwēle $i$ ?

asēěčè.

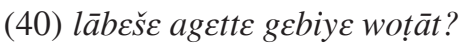

$q \bar{e} s s \varepsilon^{60}$

\section{Body Parts}

(41) bibbimazer țabbuçē qețțōo

bābbimazer tobbuçç̌e qețțō? qərb.

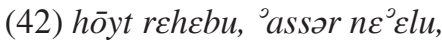
sāse te ${ }^{\circ} \bar{e} b \varepsilon l u$ ? yin, วontābitwe วosən.

\section{Animals and plants}

(43) țēm bāre gwāre gwāre? gōnds.

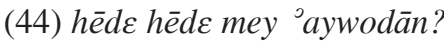
gōnde.

(45) bušs bāre gwāre gwāre? wonet.

(46) mwālt mwālt bert ${ }^{\circ}$ arōt ¿arōt midēe? yelām țub.

(47) hubd lām bemāger der? tōhān.

(48) bețēm gō țēm lām? yedumi qumāl.
When one carries it, is a corpse, when one takes it into the hands it is a lion? Spear.

The youngsters from the däga-region ${ }^{59}$ close the door and dance?

Thick local beer.

After one beats it from this side and after one beats it from that side and brings out a young cow?

Butter.

She ties her backside and goes to the market?

Butter.

At this side one handful of fire wood, at that side one handful of fire wood? Eyelash.

Two found it, ten took it, thirty welcomed it? Eye, hand and teeth.

A black ox in every garden?

Ant.

It goes and goes but does not cross the water?

Ant.

Red ox in every garden?

Termite.

At daytime it is like a stick and at nighttime like a river?

Udder of a cow.

A pregnant cow on top of the wall?

Bug.

In a black wood a black cow?

Hair louse.

${ }^{59}$ The region is somewhat elevated and therefore cooler. In such a place the main crop is barley, which is used for preparing the thick beer.

${ }^{60}$ Butter and cheese, too, are wrapped in leafs from Ensete edulis which is then tied together at one side only. 
(49) toṭqēlləb yindctkō, totqune tər yabōt mištəkō?

ənžāt.

(50) hullem gən terērēt tiyānž yalfān?

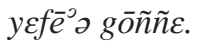

When she feeds she does it like a mother, when she pinches she does it like a step-mother?

Bee.

When it goes it always looks back?

Tail of a goat.

Even if I tie the belt of my mother again and again it does not get finished?

Way.

It goes and goes and it never ends?

Way.

The tree is big, the child is alone and the sheep are plenty — what is it?

Heaven, moon and stars.

When I look at him he looks at me, when I send him away he refuses?

Shadow.

(55) bingwe tegōlte šənkurt təlēțtāt? onqorfit.

(56) ənnє gār mən yəmēleyān? çวlme.

(57) ənney anney tihēd aytərān? nəfās.

(58) bemey wust tom gebe čelbe aybel, gōm gebs kōšš aybel? dābenc / gunğ $\bar{e}$.

(59) bescmāy yantere, bedečče yegedere? qōtō.

(60) binğiye ’aytēnzān, bin `aytrān? hāwe.

\section{Others}

(61) binğiye bētenkuy baremetiye le $\varepsilon^{\circ}$ mmkuy? kutb.

(62) yegered lubām bezวlāmwe bayr təhēdāt?

zāntcle.
I distributed it with my hand and collected it with my tongue?

Written documents.

The skilled female child goes during rain and sunshine?

Umbrella. 


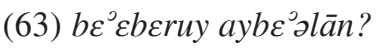
ğenāys.
It does not grow after it was planted? Corpse.

\section{Zay Riddles}

\section{House and household utensils}

(64) țìt gered gār tāhìdāt?

kurrāzi [Zay].

(65) āyìy leggob leggob təbəlāt, geredi lehəd lehəd təbəlāt? wof̣̣̌iwā meği [Zay).

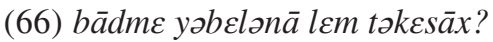
qerši

(67) sīlāle māf hinkutinīf?

belbele [Oromo].
A small female child keeps the house going?

Kerosene lamp.

The mother says let's stay let's stay, the daughter says let's go let's go?

Big and small mill stones.

We eat together, why are you getting thin? Spoon.

He looks at you, why don't you cut so mething for him?

Door.

\section{Food}

(68) sānni adi lege dāke [Oromo]? išičci [Zay].

A white cow swims on a river?

Butter.

\section{Working tools}

(69) lāqōti lāmōti yāytəšbər?

qūnānūnu [Zay].

(70) hādōnn nama lālti ilmōn

name ñāti?

qewwe [Oromo].

One throws it to and fro but it does not break?

Spindle.

The mother looks at the person, the child eats the person?

Gun.

\section{SUMMARY}

The topic of this article is the result of long-lasting interactions among different communities in Central Ethiopia and the development and change of the respective culture(s) and languages. These contact-induced cultural and languages changes are exemplified through a cross-language description of riddles among the Muher, Wolane and Zay communities. The language and cultural situation in Ethiopia, in general, and in the Gurage region, in particular, is presented with a concise survey of the relevant literature. The riddle is dealt with as research topic in verbal art from a typological viewpoint, and an overview of research on riddles in Ethiopia is presented. The genre of riddle in the Gurage languages Muher, Wolane and Zay is discussed in formal, semantic and linguistic terms. Finally, the results are summarized in a conclusion. The riddles of the respective languages are listed in two appendices. Appendix I contains introductory and concluding frames, and Appendix II enumerates the riddles. 